\title{
The Role of Universities of Georgia in Providing Continuing Education Courses of Local Self-Government Public Servants
}

\author{
Maka Kordzadze ${ }^{1, *}$ \\ ${ }^{1}$ Administration Department, Ilia State University, Tbilisi, Georgia \\ *Correspondence: Administration Department, Ilia State University, Cholokashvili 3/5, 0162, Tbilisi, Georgia. \\ E-mail: maka.kordzadze@iliauni.edu.ge
}

Received: December 12, 2019

Accepted: January 6, $2020 \quad$ Online Published: April 6, 2020

doi:10.5430/wje.v10n2p69

URL: https://doi.org/10.5430/wje.v10n2p69

\begin{abstract}
The present-day rate of development of the society and technologies in any sphere requires from the employee constant raising of qualification and gaining new knowledge and skills - continuous professional development. Life-long learning, continuing education is equally important compared with initial degree education. This leads to the necessity of ensurng continuing education in especially significant areas for the country in which the country's

leading universities have to be actively involved. Provision of continuing education for local self- government public servants in recent years in the context of the self - government reform gained special actuality in Georgia. The aim of the article is to underline the significant role of universities of Georgia in developing and providing continuing education courses to public servants of local self-government and identifying those measures which will promote active involvement of universities in this process.
\end{abstract}

Keywords: continuing education, university, local self-government, public servants

\section{Introduction}

The terms "continuing professional education, lifelong learning" and respective disciplines got established in the educational space since 1960s and serve as the "order" of the so-called knowledge-based society. These days, the importance of continuing education is stressed in significant international recommendation documents too regulating higher education. The Bologna Policy Forum Report of the European Higher Education Association (EHEA) in Paris, 2018, clearly outlined the attitude of member states towards continuing education - "Continuous education (CE), continuous professional development (CPD) and open education are cornerstones in lifelong learning". "In view of the needs in society, the developments in these areas must be urgently integrated in the Bologna Process and the European Area of Higher Education" (European Association of Distance Teaching Universities [EADTU], 2018); The Bologna Process Leuven Communique "Bologna Process 2020 - the European Higher Educational Space in the New Decade" clearly underlines the necessity of lifelong learning, which, according to the communiqué, "involves obtaining qualifications, extending knowledge and understanding, gaining new skills and competences or enriching personal growth. Lifelong learning implies that qualifications may be obtained through flexible learning paths, including part-time studies, as well as workbased routes" (Bologna Process 2020, 2009). The document also mentions that "lifelong learning should be supported by adequate organizational structures and funding" (Communiqué of the Conference of European Ministers Responsible for Higher Education, 2009). So, providing continuing education courses is a new challenge for universities and universities should respond with the respective initiatives to these challenge.

One of the initiatives with which universities of Georgia may respond to this challenge is providing continuing education courses to local self-government public servants. The need and actuality of developing this sector of continuing education was especially identified in rapid succession of the self-government reform ongoing in Georgia. Aims and interests of universities and local self-government in the sector of continuing education of public servants of the local self-government units significantly intersect one another and universities in Georgia may play a leading role in providing local self-governing units with continuing education courses fine-tuned to the needs of their public servants. Timely and adequate reaction of the university to the continuing education needs of public servants of local 
self-governing units and active involvement in providing continuing education courses will help self-governing units to more effectively ensure raising of qualification of employees through high level continuing education courses. On the other hand, providing these courses will help universities to meet the requirements of Bologna, increase the role of universities in providing qualified staff to the labor market of the country and give them as well the possibility to receive additional income.

\section{Challenges of Continuing Education in Universities of Georgia}

As it has already been stated, support of lifelong learning and continuing education by universities is one of the key requirements of Bologna process. Since 2005 Georgia has been connected to the Bologna Process and since then has been regularly making steps towards being integrated into the European educational space to meet Bologna requirements. In recent years certain steps were made towards meeting the obligations related with lifelong learning. For example, in one of the standards of authorization of higher educational institutions operating in Georgia mission and strategy - the obligation was reflected that higher educational institution supports implementation of the principle of lifelong learning whereas the criteria of respective assessment states: Higher Education Institution plans and implements activities supporting lifelong learning (Ministry of Education and Science of Georgia, 2010).

To what extent activities of universities of Georgia are systematic and intensive in respect with cornerstone in lifelong learning - continuing education, how the activities correspond with international standards and Bologna requirements is determined by investigating and analyzing the following three specific obvious indicators: a) whether the university has defined a responsible structure for supplying continuing education; $b$ ) the amount of continuing education courses provided by the university; c) the spectrum of spheres of continuing education; to search for the data about these indicators, we will use the information published at university websites since proper functioning of websites and placing all the necessary information on them is one of the requirements of authorization standards of higher educational institutions operating in Georgia. To be more specific, the criteria of fulfilling this standard states that the official website of University serves the communication and information giving function and among other pieces of information there a catalogue of educational programs is placed as well as all available services; information is updated regularly so that the interest of getting information within reasonable timeframe is followed (Ministry of Education and Science of Georgia, 2010).

Research outcomes are as follows: based on present-day data in Georgia, there are 50 authorized universities. They are located by regions in the way depicted in Table 1 .

Table 1. Authorized Universities of Georgia by Region

\begin{tabular}{cccccccc}
\hline $\begin{array}{l}\text { Total authorized universities/ } \\
\text { authorized state universities }\end{array}$ & Tbilisi & Ajara & Imereti & Inner Kartli & Kakheti & Samegrelo & $\begin{array}{c}\text { Samtskhe- } \\
\text { Javakheti }\end{array}$ \\
\hline $50 / 17$ & $36 / 9$ & $7 / 2$ & $2 / 1$ & $2 / 2$ & $1 / 1$ & $1 / 1$ & $1 / 1$ \\
\hline
\end{tabular}

Nineteen universities out of $50(38 \%)$ have their defined structural unit responsible for adult and continuing education whereas 15 universities $(30 \%)$ carry out respective training courses. It is worth noting that according to the data of 2009, only $6 \%$ of universities had such a structural unit whereas $13 \%$ of universities carried out continuing and adult education courses (Darchia I., 2009). Out of 15 universities, which today offer continuing education courses, 5 are the ones with a very specific narrow profile - medical, art, aviation, naval. Respectively, continuing education courses offered by them are intended for a specific beneficiary - doctors, actors, pilots, sailors. Therefore, these days, out of 50 universities 10 ones are those that offer wider stata of society and representatives of a wide spectrum of fields continuing education courses. 8 out of 10 universities are located in Tbilisi ( 2 state, 6 private) whereas 2 universities are in regions (both are state ones). 2 universities located in the region offer 40 courses of continuing education. Both universities have a structure responsible for continuing education. All 10 universities overall offer up to 200 training courses to interested people in various areas of teaching. (This amount does not include the 60-credit teacher preparation program and language courses). Among the areas of teaching of provided courses are: management, law, education, economics, finances, information technologies, psychology, public relations, public administration, local government, project management, health administration, marketing, personnel management, democracy and human rights, environmental protection and ecology, media, labor safety, project management, fundraising, social and public transfer skills, etc. The above-mentioned continuing education courses are intended for various groups of beneficiaries, only one university (in Tbilisi) provides special courses focused on 
raising the qualification of public servants of self-government.

On the basis of the outcomes gained, the following conclusions can be made:

1. Intensity of providing continuing education in universities of Georgia increased in recent years. Namely, relatively more universities are involved in providing continuing education courses. To what extent these training courses are demanded, how frequently they get conducted, how far they manage to compete other organizations providing continuing education, is the interesting issue for another separate research.

2. The spectrum of supplied continuing education courses is quite comprehensive. Besides, the fields of training: management, law, education, economy, finances, information technologies, psychology, public relations, local government, project management, health administration, marketing, personnel management, democracy and human resources, environment protection and ecology, media, labor safety, project management, fundraising, social and general transferring skills, etc. should, as a rule, be interesting and necessary for the public servants of various structures of local self-government.

3. Despite positive dynamics mentioned above, majority of universities have still not been involved in providing continuing education courses and their activities in this respect do not comply with international standards and Bologna recommendations. Compliance with the demands of local standards of authorization is also under the question mark.

4. Involvement of universities located in regions in providing continuing education courses is low - only 2 universities out of 14 regional ones offer continuing education courses. It also needs to be stated here that regular and systematically provided availability of adult and continuing education serves as a general problem these days for the population of regions of Georgia. Training courses carried out episodically on the spot with effort of donor organizations within the scope of various projects can't change the situation and in case of the need for going through the continuing education course, those living in regions mostly have to arrive to Tbilisi. This, obviously, creates additional barriers and leads to additional spending of both time and financial resources. Active and intensive involvement of regional universities in preparing and providing continuing education courses is subject to being largely taken care of. The problem related with availability itself applies to continuing education of those employed in self-government, which deserves special attention based on the actuality of the issue.

All this enables us to conclude that a positive trend is observed in universities of Georgia towards more active participation in continuing education. However, the speed of positive dynamics is slow. Respective measures need to be carried out, which will promote more cooperation among universities in the country in respect with providing continuing education courses. Active co-participation of in local self-government public servant's continuing education may positively change the situation more rapidly, especially, in regional universities.

\section{Importance and Actuality of Local Self-Government Public Servants' Continuing Education}

Caring about raising qualification and continuing education of public servants employed in self-government gained special actuality in Georgia as a result of the self-government reform which started in 2013. High qualification and professionalism of those employed in local government is the key defining condition of efficient operation of self-governing structures whereas efficient and successful carrying out by the local government of administrative, social, infrastructural, educational and other functions imposed is the most significant for the development of the country. It is worth-noting that the European Charter on Local Self-Governments which entered into force on April 1, 2005 for Georgia states that "the conditions of service of local government employees shall be such as to permit the recruitment of high-quality staff on the basis of merit and competence; to this end adequate training opportunities, remuneration and career prospects shall be provided" (Council of Europe, 1985). At the same time, numerous pieces of research conducted by international and local organizations in the area of local government in recent years reveal that qualification of public servants of local government in Georgia in most cases is not enough for respectively carrying out their own work functions and responsiblities (Government of Georgia, 2014); The fact that public servants of municipalities frequently do not have sufficient qualification to organize activities defined by legislation, is mentioned in the annual report of 2016-2017 of developing local democracy in Georgia. (Losaberidze, Kakhidze, \& Katamadze, 2018)

The importance of the requirement of the "European Charter on Local Government" related with ensuring raising of qualification of emplyed in local government was well understood by Eastern European countries and the reforms of public servants carried out since 90 -ies of the previous century in these countries involved introduction of respective systems of providing lifelong professional education and raising of qualification of those employed in local as well 
as central governments (Lucking, 2003).

To raise qualification of local self-government public servants and ensure continuing education, regular steps have been made in recent years in Georgia as well. The first such signfiicant one was to set the obligation for municipalities by Organic Law of Georgia - Local Self-Government Code adopted in 2014 with the view of directing not less than one percent of salary appropriations towards raising qualification of their servants. As the next steps can be regarded: "The Conception of Continuing Education of Public Servants of Local Self-Government" approved by the decree of the government of Georgia on May 29, 2014 and decree of the government of Georgia on "Principles and Rule of Functioning of Continuing Education System of Local Self-Government Public Servants, Rights and Responsibilities of Agencies involved in It" which was adopted on July 7, 2015. The decree of the government of May 22, 2018 on "Approving the Rule of Determining Professional Development Needs of a Professional Public Servant, Professional Development Standard and the Rule" is the most recent step made accoridng to which professional development standard and rule of the professional public servant in Georgia was defined, including, employed in local government and compulsory training was identified for acting and starting public servants.

These days out of a total at about 74000 public servants in Georgia there are more than 10000 public servants of local self-government bodies (Institute for Development and Freedom of Information [IDFI], 2013) who require systematic and regular provision of training courses of many various areas, content and formats. The most large scale investigation of continuing education needs of local self-government public servants conducted so far in 2016 with coordination of LEPL Vano Khukhunaishvili Center for Effective Governance System and Territorial Arrangement Reform and UNDP support to meet the obligations defined on the basis of the above-mentioned decree of the government of Georgia on "Principles and Rule of Functioning of Continuing Education System of Local Self-Government Public Servants, Rights and Responsibilities of Agencies Involved in It" not only proved the necessity and actuality of continuing education of public servants of municipalities but also identified many specific areas of training in which these servants need to raise qualification (United Nations Development Program [UNDP], 2017). The author of the given article, who at the time of conducting this research, used to work at the managerial position at the LEPL Vano Khukhunaishvili Center for Effective Governance System and Territorial Arrangement Reform, personally took part in planning and coordination of investigation and analysis of results.

Investigations of training needs analysis of public servants of local self-governing units were conducted by the human resources management structures of the same units, which previously went through respective training courses. Research, in which 74 self-governing units of Georgia out of 76 took part, gave the following outcome: 924 orders of various content and format training courses for overall 4838 municipal public servants were identified for 2017. Research also demonstrated that municipal public servants express readiness and desire to go through respective continuing education courses. Among the required courses there were special as well as those developing trasnfer skills and knowledge. Mostly demanded areas of continuing education which were identified are depicted in Table 2.

It needs to be emphasized that 1744699 Georgian laris were accumulated by the municipalities for 2017 to provide this learning which is not little amount. In general, complying with the requirements envisaged by the new Organic Law of Georgia - Local Self-Government Code - directing not less than $1 \%$ of salary appropriations towards raising qualification of its employees will lead to the accumulation of more than 2000000 laris in this segment of education on annual basis (United Nations Development Program [UNDP], 2017). Undoubtedly, purposeful and efficient spending of the mentioned amount is extremely significant.

All the above-mentioned clearly illustrates that continuing education of public servants of local self-government these days is not only an actual and important topic but also a significant challenge and arena for continuing education providers in the country, including, universities. However, as it seems, so far the level of involvement of universities in this process is low. This was once again proved by the fact that within the scope of the same investigation, participation of universities in the pilot register of training courses for public servants of local self-government prepared in parallel with the learning needs analysis of public servants of local self-government was completely insignificant. 122 various training courses were given in this register then (United Nations Development Program [UNDP], 2017) which were developed by 23 various providers. These providers were mainly training centres at various ministries, Ltd. training centers and NGOs whereas only 1 university was involved with 5 programs. 
Table 2. Mostly Demanded Areas of Continuing Education of Municipal Public Servants

\begin{tabular}{lcc}
\hline A list of fields & $\begin{array}{c}\text { Amount of required } \\
\text { trainings }\end{array}$ & $\begin{array}{c}\text { Amount of public } \\
\text { servants }\end{array}$ \\
\hline Administrative proceeding & 62 & 529 \\
Human resource management & 36 & 480 \\
Local self - government legislative regulation Issues & 57 & 375 \\
General skills of local government servants & 19 & 317 \\
Project preparation, management and monitoring & 8 & 308 \\
Public procurements & 49 & 287 \\
Main issues of economic development planning of municipalities & 38 & 285 \\
Office programs & 23 & 234 \\
Construction permits & 48 & 218 \\
Formation, approval, execution and calculation of the municipality budget & 53 & 213 \\
Financial management, accounting & 42 & 156 \\
Public relations & 41 & 165 \\
Effective service of citizens & 23 & 145 \\
Property management & 50 & 140 \\
Method of preparing legislative acts & 32 & 130 \\
Spatial-territorial planning & 35 & 104 \\
Issues of social affairs and healthcare of municipality & & 110 \\
Internal audit & 38 & 74 \\
Managing youth issues & 38 & 54 \\
Supporting development of tourism & 26 & 50 \\
\hline
\end{tabular}

\section{Co-participation of Universities of Georgia in Continuing Education of Public Servants of Local Self-Government a Mutually Beneficial Process}

Demands towards European Universities in respect with providing continuing education opportunities are gradually growing. As it was stated, more and more focus is made on lifelong and continuing education implementation in Bologna documents as well. This is natural since to retain the traditional role of establishments as main knowledge creators and providers, universities should respond successfully to those new challenges which they face today in the "knowledge-based" society: on the one hand, knowledge is being increasingly created outside universities, in various organizations and establishments, such as, governmental or non-governmental organizations, private commercial organizations, research and consultation companies, whereas, on the other hand, due to constant changes and innovations in all spheres, frequently, it is not enough to go through traditional academic programs to be able to be competitive at the employment market and the university gradute needs to constantly gain new competencies and update knowledge and skills. In response to these challenges, universities of European countries are trying to offer the public more job market oriented learning in cooperation with employers, expand forms and methods of providing knowledge, offer the public more professional development and continuing education courses in parallel with traditional academic programs.

Universities will have to embrace a new more social, and market-oriented role based on cooperation in diverse networks in order to be able to address economic concerns, enhance new ways of producing knowledge and provide education and research that meets the needs of knowledge society that is expecting high quality research and education that guarantees wide access to knowledge, continuous knowledge production, and equal opportunities to all for lifelong learning (Shnelmann, 2015).

Besides, in recent years of advocating and supporting continuing education in universities, associations, national and regional networks are more and more intensively created by universities. The European Universities Continuing Education Network (EUCEN), which these days is the largest multidisciplinary organization of lifelong learning and continuing education in Europe, was established in 1991, upon the initiative of 15 countries and based on 2018 data, it got 171 members of 34 countries united, including, universities as well as 15 national and 2 regional networks of lifelong learning and continuing education.

It is even more obvious at this background that if universities of Georgia wish not to stay behind leading European ones in respect with carrying out continuing education, they should express more initiative in taking part in this area of education. Participation in continuing education of public servants, including, those of local self-government, may 
serve as one of such initiatives. Co-participation of universities of Georgia in continuing education of public servants of self-governing units will not only respond to the Bologna requirements but also give immediate assistance to these universities to respond to modern challenges, be constantly actual at the country's labor market, make significant contribution in the development of the country, providing qualified staff to it, which is the key objective of any leading university. In other words, leading universities are constantly motivated to make timely and adequate reaction to those various types of educational needs which appear in the country and make their educational resources available for as much wide audience as possible.

The fact needs to be emphasized that preparation and provision of continuing education courses for public servants, including, those of self-governing units, is specific pragmatic interest of universities since this will be an additional sources of income generation-training of public servants these days is a new order of the labor market and universities are able to ensure timely response to this order, anticipate in advance and fill up the expected market gap by offering respective service and products. This possibility and financial interest are even more clearly observed in the training sector of local self-government public servants in which municipalities accumulate respective amounts within the scope of obligations imposed by the Local Self-Government Code for training their public servants.

In the process of self-initiating co-participation in continuing education of public servants, including, those of local self-government, universities can use best practices of universities of European countries where such kind of participation is a widely accepted practice. The findings of some studies suggest that universities, as providers of continuing education courses for public sector servants, are gaining importance and interest in different countries around the world (Borins, 1999). The role of universities in this sector got especially identified since 90-ies of the previous century as a result of reforms which started in public service of eastern Europe and post-soviet countries envisaging raising of qualification and continuing education of public servants. Therefore, it has educational challenges in these countries. Universities then responded to these challenges with respective initiatives. Part of special training centres of training public servants of central and self-governing units in Latvia and Lithuania was situated in universities. These centres used to be especially active. For example, the Municipal Training Centre, part of the Kaunas University of Technology, with 1 full-time, 1 part-time and 13 contractual staff, delivered over 440 seminars and conferences, to political and administrative officials, with a combination of municipal, foreign and self-financing (Lucking, 2003). A similar tendency was observed in Hungary where the overwhelming majority of training institutions are law faculties in universities; another group includes university departments (such as, public affairs, political science) which include larger elements of public policy and public management (Lucking, 2003). Involvement of universities in continuing education of public servants, including, those in local self-government units, is high in Balkan countries as well (Regional School of Public Administration [ReSPA], 2008;)

It is worth-mentioning that in 2000 s, regional universities got actively involved in training of local self-government public servants in Armenia on the basis of contracts with local self-government units and they even got significant benefit from such educational activities (Lucking, R.,2003).

To what extent participation in continuing education of local self-government public servants may be useful and favourable for the regional universities of the country should be separately identified. Here, let us deviate slightly and additionally stress the role of regional univerisities of Georgia not only in continuing education of local self-government public servants but also ensuring provision of the possibility of lifelong learning of the population of regions. Providing lifelong learning services on the spot to the population of the region is considered to be significant for the regional population and, therefore, in a number of European countries special adult education establishments are functioning in regions and municipalities. There are two successful examples: the so-called Volkshochschules in Germany can be considered as an especially successful model of such establishments. Throughout the country more than 100 Volkshochschules (vhs) located in various municipalities serve as municipal centres which give adults the possibility of getting further education and training, offer them training courses, lectures and seminars in such areas as languages, health, culture, creativity, professional training, society and politics, „it is a hub for people of all ages and backgrounds” (Weber \& Wittpoth, 1999). Actvities of migros klubschule in Switzerland are also famous and successful which serve as largest adult education institutions there. In Switzerland there are 50 migros klubschules from Aarau to Zurich, which annually provide more tha 600 courses to approximately 400,000 course participants((Weber \& Wittpoth, 1999). The fact that Volkshochschule and migros klubschule are respectively flexible in adapting to local requirements and the specific learning needs of the local public is regarded as their main strength. It also needs to be mentioned here that similar centers in Georgia (overall, 11 small centers) were established within the framework of the respective project of the Georgian representation of the International Cooperation of the German Adult Education Association (DVV international). Naturally, the aim of the international project is to make sure that its outcomes are used by the country with the view of creating stable systems in this 
direction. It is indicated as the recommendation in the research of activities of the mentioned project carried out in 2017 that research will serve as supplementary material for the process of establishment of similar Adult Education Centers in the future (Deutscher Volkshochschul-Verband International [DVV], 2017)

Obviously, creating adult education centers in Georgia locally, in regions and municipalities, is not only useful but also essential. At the same time, for such a small country as Georgia, the role of adult education centers in regions is advisable to be carried out by the authorized universities of these regions and make sure such centers serve as the structures of lifelong learning of universities. Regional universities should become educational hubs of the above-mentioned type in regions. As it can be seen, authorized universities are situated in Tbilisi and 6 various regions. If we look at the geographical location of these universities, we will see clearly that in case of respective initiatives and readiness, they successfully provide availability of lifelong learning service to the population of Georgia. In terms of the territory, universities of Tbilisi are mostly accessible for the population of Tbilisi, Lower Kartli and Mtskheta-Mtianeti. As for the Kakheti population, Telavi University is the option whereas Gori University suits the population of inner Kartli. Kutaisi University is for the population of Imereti, Zugdidi University - for those living in Samegrelo-Zemo Svaneti, Kutaisi University is the option for Racha-Lechkhumi and Lower Svaneti as well, Akhaltsikhe University - for those living in Samtskhe-Javakheti and University of Batumi - population of Ajara and Guria. Besides, the way from even the most remote village of the respective region to the regional university takes maximum 2-2,5 hours. It is necessary to take respective initiatives, otherwise, in terms of readiness of universities, it is simple to take care of things, especially, without extra expenses from universities. The following circumstances condition the following: based on the limited amount of the population of Georgia, the qualified human resource in many spheres is limited to a certain extent. Therefore, to a large extent, educational activities with various non-government and private organizations are carried out under the aegis of non-government or private organizations by those professionals for whom universities are the main area of carrying out educational activities. Therefore, universities will be able to practically provide adult education through their own resources. Besides, universities have the necessary infrastructure and technical equipment in place for providing such educational activities. In other words, everything that a private, non-governmental or donor organization has to rent to conduct the training course in the region at additional cost and, which, as a rule, overall, leads to substantial increase of the total amount of providing this or that particular course. All this, obviously, applies to the sector of adult education which implies continuing education of local self-government public servants - here, as well, regional universities are able to offer quite varied training courses locally with their resources in terms of both the content and the form of instruction. What needs to be essentially mentioned here is such a significant issue as quality assurance of provided courses. Authorized universities, in all of which quality assurance services are functioning, are able to successfully provide high quality of training courses provided.

Motivation of universities situated in the regions of Georgia to get involved in lifelong learning of public servants of local self-government units should be additionally raised by other factors: first of all, it is the function of regional universities to respond to educational needs of the population of municipalities of their regions and by doing so actually carry out the role of the main educational and cultural hub of the region. Besides, obviously, the fact that the municipalities situated in the region took active part in training the municipal servants of their regions is logical and beneficial coupled with the fact that the amounts defined by the Local Self-Government Code obligation by municipalities for such trainings are used by the universities located in the same region and this amount is used for the capacity development and staff salaries of universities.

The above argumentation partially indicates not only the fact why universities should get interested to be involved in municipal public servants' continuing education but also why it is useful for the municipalities of Georgia itself so that only through cooperation with universities of Georgia they will ensure continuing education of their servants. Additionally, as it was reported, the learning needs of public servants of municipalities are quite voluminous and varied. The main objective of management of municipalities is to fully meet these needs and efficiently spend $1 \%$ of salary appropriations allocated for this as it is indicated in the Local Self-Government Code. This is not an easy task and heads of local self-governing units need to learn how to initiate and sustain successful partnerships with various suppliers of training courses. Self-governing units should turn into active clients ordering training courses from being passive users of them. They should themselves care about making training course they provide of high quality and commensurate with the training needs of public servants of municipalities. Self-governing units can successfully meet these objectives in cooperation with the universities placed in the region on the basis of the respective contract. Through these contracts it is possible to achieve maximum availability of continuing education courses for municipal public servants, quality of these courses, wide coverage of training needs of servants, flexibility of supplying continuing education courses and cost efficiency of teaching. 
As it can be seen, there are a lot of arguments of why universities and self-governing units should cooperate in the sector of providing on-going continuing education courses to the public servants of local self-government. As it seems, respective supporting measures need to be provided for kicking off the cooperation process and developing it.

\section{Recommended Measures for Active Involvement of Universities in Continuing Education of Local Self-Government Public Servants}

1. Improving the authorization standard of universities in respect with continuing education is the recommended measure to be implemented at the systemic level in the educational system. As it was observed, these days the obligations set towards universities in the lifelong learning sector for authorization are quite simple and general. Namely, they get limited just with the obligation that high educational institution supports implementation of the principle of lifelong learning which is proved by the following criteria - the university plans and implements the measures supporting lifelong learning. To meet this standard does not oblige the university to make supply of continuing education systematic. At the same time, the European Universities' Charter on Lifelong Learning which had been developed by 800 member universities of the association, numerous stakeholder organizations, students and representatives of business, sets much wider and specific obligations towards the university in respect with lifelong learning. The charter calls for universities to meet those 10 well-structured obligations with the view of implementing lifelong learning among which are "embedding concepts of widening access and lifelong learning in their institutional strategies, providing education and learning to a diversified student population, give appropriate guidance and counselling services, embracing lifelong learning in quality culture, consolidating reforms to promote a flexible and creative learning environment for all students, developing partnerships at local, regional, national and international level to provide attractive and relevant programmes, acting as role models of lifelong learning institutions" (European University Association [EUA], 2008). It is purposeful to review the present standard and criterium of authorization in terms of lifelong learning and add to it the obligations of the above-mentioned charter, namely, to ensure that the standards are required to make sure the university has the policy supporting lifelong learning and possesses the mechanisms for its implementation whereas the crietaria of making respective assessment involve reflection of activities to be implemented in respect with lifelong learning and continuing education in the strategic and action plans and the budget of the university, defining the structure responsible for these activities, making available the documentation verifying permanent cooperation with employers and knowledge exchange.

2. While iniating co-participation in continuing education of local self-government public servants, it is recommended for universities to take into consideration in lifelong learning support policy and mechanisms cooperation with specific sector ministries on such issues of signing the memorandum with them on partnership as joint development and provision of various training courses to meet the needs of continuing education of public servants of local self-government using the resource of academic personnel of the university and organize joint seminars, conferences and workshops.

3. It is recommended to start systematic cooperation of regional universities with municipalities of respective regions in respect with providing the latter with continuing education courses for their public servants (It may also be necessary to organize a special information campaign in this direction). On the basis of conducting training needs analysis, municipalities may define the training needs of their public servants annually, prepare respective one-year training plans which will reflect the names of continuing education courses, beneficial time for provision and forms (face to face training, online training, seminar, coaching, etc.) with the respective budget and submit these training plans to universities in regions for further discussion. Eventually, respective agreements will be signed among universities and municipalities on annual basis in which obligations of both parties will be reflected in terms of providing continuing education courses to local self-government public servants.

4. It is recommended to make sure respective structures of universities study and share the experience and best practices of European universities in the direction of co-participation of universities in continuing education of local self-government public servants.

\section{References}

Bologna Process 2020. (2009). Communiqué of the Conference of European Ministers Responsible for Higher Education, Leuven and Louvain-la-Neuve. Retrieved from https://www.eurashe.eu/library/modernising-phe/Bologna_2009 Leuven-Communique.pdf

Borins, S. (1999). Trends in training public managers: A report on a commonwealth seminar. International Public Management Journal, 2(2), 299-314. https://doi.org/10.1016/S1096-7494(00)89039-X 
Council of Europe. (1985). European Charter of Local Self-Government. Retrieved from https://rm.coe.int/168007a088

Darchia, I. (2009). Development and implementation of LLL programmes at higher Education institutions in Georgia, National Tempus Office. Retrieved from http://erasmusplus.org.ge/files/files/Guide_ULLL-ge.pdf

DVV International, Georgia Country Office. (2017). Adult Education Centers in Georgia. Retrieved from http://www.dvv-international.ge/fileadmin/files/caucasus-turkey/Georgia/AECs_in_Georgia_ENG_without_pho tos.pdf

European Association of Distance Teaching Universities [EADTU]. (2018). Position paper on the Bologna Process and EHEA Bologna Policy from http://www.ehea.info/media.ehea.info/file/2018_Paris/60/7/2018-EHEA-EADTUpositionpaper_947607.pdf

European University Association [EUA]. (2008). European Universities' Charter on Lifelong. Learning. Retrieved from

https://eua.eu/downloads/publications/european\%20universities\%20charter\%20on\%20lifelong\%20learning\%20 2008.pdf

Government of Georgia. (2014). Decree \#959 on approving the concept of continuing education of local-self-government public servants. Retrieved from https://www.matsne.gov.ge/ka/document/view/2365571?publication=0

Institute for Development and Freedom of Information [IDFI]. (2013). Statistics of Public Servants in the Public Authorities of Georgia in Terms of Gender. Retrieved from https://idfi.ge/en/statistics-of-public-servants-in-the-public-authorities-of-georgia-in-terms-of-gender

Losaberidze, D., Kakhidze, I., \& Katamadze, A. (2018). Annual report of developing local democracy in Georgia for 2016-2017. Retrieved from https://osgf.ge/wp-content/uploads/2019/03/Democracy_2019.pdf

Lucking, R. (2003). Civil Service Training in the Context of Public Administration Reform: A Comparative Study of Selected Countries from Central and Eastern Europe and the former Soviet Union (1989-2003). Lessons on Best Practice in the Approach to Civil Service Training, United Nations Development Programme (UNDP), Bosnia and Herzegovina.

Ministry of Education and Science of Georgia. (2010). Order N 99/N on the Approval of the Educational Institutions Authorization Charter and of Authorization Fees. Retrieved from https://eqe.ge/res/docs/2019091213120399N.pdf

Regional School of Public Administration (ReSPA). (2008). Civil service training system in the western Balkan region. Retrieved from https://www.oecd.org/countries/croatia/42331015.pdf

Shnelmann, L. (2015). University in Knowledge Society: Role and Challenges. Journal of System and Management Sciences, 5(4), 84-113.

United Nations Development Program [UNDP] Georgia. (2017). Fostering Regional and Local Development in Georgia, Final Evaluation Report. Retrieved from https://erc.undp.org/evaluation/evaluations/detail/8496

Weber, K., \& Wittpoth, J. (1999). Discourse, structure and practice of continuing education; A comparison between Switzerland and Germany. International Review of Education, 45(5/6), 547-560. https://doi.org/10.1023/A:1003891327534 